\title{
Human cytomegalovirus infection enhances cell proliferation, migration and upregulation of EMT markers in colorectal cancer-derived stem cell-like cells
}

\author{
WAN HUAI TEO ${ }^{1}$, HSIN-PAI CHEN ${ }^{2}$, JASON C. HUANG ${ }^{1,3}$ and YU-JIUN CHAN ${ }^{2,4,5}$ \\ ${ }^{1}$ Department of Biotechnology and Laboratory Science in Medicine, School of Biomedical Science and \\ Engineering, National Yang-Ming University; ${ }^{2}$ Division of Infectious Diseases, Department of Medicine, \\ Taipei Veterans General Hospital; ${ }^{3}$ AIDS Prevention and Research Centre, National Yang-Ming University; \\ ${ }^{4}$ Institute of Public Health, School of Medicine, National Yang-Ming University; ${ }^{5}$ Division of Microbiology, \\ Department of Pathology and Laboratory Medicine, Taipei Veterans General Hospital, Taipei, Taiwan, R.O.C.
}

Received July 10, 2017; Accepted September 4, 2017

DOI: $10.3892 /$ ijo.2017.4135

\begin{abstract}
Increasing evidence suggests a link between persistent human cytomegalovirus (HCMV) infection and cancer. Although the role of HCMV in cancer is still elusive, recent studies revealed the presence of HCMV nucleic acids and proteins in different cancer types such as glioblastoma,
\end{abstract}

Correspondence to: Professor Yu-Jiun Chan, Division of Microbiology, Department of Pathology and Laboratory Medicine, Taipei Veterans General Hospital, 201 Shih-Pai Road, Sec. 2, Taipei 11247, Taiwan, R.O.C.

E-mail: yjchan@vghtpe.gov.tw

Dr Jason C. Huang, Department of Biotechnology and Laboratory Science in Medicine, School of Biomedical Science and Engineering, National Yang-Ming University, 155 Linong Street, Sec. 2, Taipei 112, Taiwan, R.O.C.

E-mail: jchuang2@ym.edu.tw

Abbreviations: CRC, colorectal cancer; HNPCC, hereditary non-polyposis colorectal cancer; APC, adenomatous polyposis coli; TGF- $\beta$, transforming growth factor $\beta$; HCMV, human cytomegalovirus; IE-1, immediate early 1; PCR, polymerase chain reaction; ORF, open reading frame; GBM, glioblastoma multiforme; GSC, glioma stem cell; ATCC, American Type Culture Collection; MEM, minimal essential medium; FBS, fetal bovine serum; CPE, cytopathic effect; MOI, multiplicity of infection; EGF, epidermal growth factor; bFGF, basic fibroblast growth factor; IE, immediate early; PBS, phosphate-buffered saline; EMT, epithelial to mesenchymal transition; RT-PCR, reverse transcription polymerase chain reaction; cDNA, complementary DNA; DEPC, diethyl pyrocarbonate; GAPDH, glyceraldehyde 3-phosphate dehydrogenase; ANOVA, analysis of variance; FZD7, frizzled-7; GSK3 $\beta$, glycogen synthase kinase 3 $\beta$; PI3K/AKT, phosphatidylinositol-3-kinase/ protein kinase; MAPK, mitogen-activated protein kinase; PTEN, phosphatase and tensin homologue; PDGFR $\alpha$, platelet-derived growth factor receptor $\alpha$; TSC2, tuberous sclerosis protein 2

Key words: colorectal cancer, human cytomegalovirus, CD44, proliferation, migration, epithelial to mesenchymal transition, WNT pathway colorectal, breast, and prostate cancers, and neuroblastoma. Although HCMV may not be directly associated with the neoplastic transformation, the presence of HCMV DNA in the tumorous tissue has been associated with altered clinical outcomes in cancer patients. However, the mechanisms involved in the association between colorectal cancer (CRC) and HCMV are unclear. In this study, we investigated the influence of HCMV infection on CRC or their derived cells. Proliferation and migration assays revealed a high infection efficiency in CRC-derived HT29 and SW480 'stem-like' cells. After 24, 48 and $72 \mathrm{~h}$ of HCMV infection, both HT29 and SW480 parental and stem-like cells showed a significant increase in cell proliferation and viability $(\mathrm{p}<0.0001)$. Moreover, HCMV infection promoted cell migration. These results demonstrate a significant phenotypic alteration in the CRC cell line upon HCMV infection. Using epithelial to mesenchymal transition (EMT) assays, we demonstrated that the EMT markers and driver genes were upregulated during the virus infection. The WNT signaling pathway, which is associated with the proliferation and migration of CRC cells, was upregulated (6-fold) in HCMV-infected cells as compared to the non-infected cells at day 7 from infection.

\section{Introduction}

According to the World Health Organization, colorectal cancer (CRC) is the third leading cause of cancer-related death in the world after lung and liver cancers. Of the 8.8 million deaths reported in 2015, 774,000 cases were attributed to CRC (1). There are at least four types of human colorectal carcinogenesis, namely adenoma-carcinoma, hereditary non-polyposis colorectal cancer (HNPCC), de novo cancer, and colitis cancer (2). Many cases of CRC are related to environmental or dietary factors rather than heritable genetic changes. These factors include the environmental and food-borne mutagens, specific intestinal commensals, pathogens, and chronic intestinal inflammation, which subsequently induce tumor development. The progression from adenoma to cancer and 
metastatic stage involves the reciprocal failure of protective mechanisms such as adenomatous polyposis coli (APC), $\mathrm{p} 53$, and transforming growth factor $\beta$ (TGF- $\beta$ ) as well as the induction of oncogenic pathways such as K-RAS and $\beta$-catenin (3-6).

For the past decade, the development of CRC is seldom being linked to infectious diseases. However, recent studies showed that the proteins immediate early 1 (IE1) and pp65 of human cytomegalovirus (HCMV) were detected in colorectal polyps and adenocarcinomas but not the adjacent non-neoplastic colon biopsy samples (7). The presence of HCMV proteins, mRNA of early genes, and DNA was demonstrated through immunochemical staining, in situ hybridization, and polymerase chain reaction (PCR), respectively $(7,8)$. In addition, our previous study reported the presence of HCMV nucleic acids in the tumorous epithelium of CRC. Furthermore, the existence of HCMV in CRC was correlated with the poor outcome in elderly group but better outcome in the younger group $(8,9)$. Dimberg et al showed that the HCMV-DNA-positive rate was significantly higher in cancerous tissue as compared with the paired normal tissue (10). Growing evidence demonstrates that HCMV infection occurs in tumor tissues and its gene products may promote important oncogenic pathways in CRC (11).

Human cytomegalovirus belongs to the subfamily of $\beta$-herpesviruses. Upon infection, it gets adapted and remains lifelong in the host. The viral replication cycle is reactivated whenever the host immunity is impaired, resulting in disease relapse (12). HCMV comprises a genome of $\sim 235 \mathrm{~kb}$ with $>200$ open reading frames (ORFs) that encode $>180$ proteins. Among these proteins, some are essential for its replication and a vast majority may interfere with the cellular and immunological functions to enable the virus to coexist with its host (13). Several studies provide evidence that HCMV proteins and nucleic acids are frequently detected in tissue specimens from patients with cancers of different origin, including cancer of colon (7,8-11), breast (14), prostate (15), and mucoepidermoid salivary gland (16) as well as glioblastoma (17-19) and neuroblastoma (20). In addition, HCMV proteins are believed to function as 'oncomodulators' in cancer. There have been a number of studies suggesting HCMV proteins such as IE, US28, pp65, non-coding RNA $\beta 2.7 \mathrm{~kb}(\beta 2.7 \mathrm{~kb})$ and other transcripts enable the virus to provide mechanisms for oncomodulation, thus enable the virus to evade from host immune and aid in the oncogenic transformation (21-23). Some of the HCMV gene products and proteins are known to accelerate cancer progression via certain pathways. Some of these pathways are involved in the suppression of the local immune response against tumors, while others are involved in the promotion of cell proliferation, apoptosis, angiogenesis and metastasis.

Increasing evidence revealed HCMV infection in glioblastoma multiforme (GBM) and glioma stem cell (GSC), which are believed to cause the recurrence of GBM after the surgery or therapy (24-27). However, the impact of HCMV infection in CRC and developing tumors is questionable, especially in colon cancer stem cell (CSC). To date, there is no well establish cell model to study the interaction of HCMV and CRC. In this direction, we studied the influence and effect of HCMV in CRC-derived cell lines.

\section{Materials and methods}

Virus infection. Thelaboratory-adapted strain of HCMV AD169 obtained from American Type Culture Collection (ATCC, USA) was propagated in confluent monolayers of MRC-5 cells (ATCC) in minimal essential medium (MEM) (Gibco, Life Technologies, CA, USA) supplemented with $10 \%$ fetal bovine serum (FBS) (Hyclone, USA). Supernatants were harvested from MRC-5 cells displaying 90-100\% cytopathic effects $(\mathrm{CPE})$ and the aliquots were store at $-80^{\circ} \mathrm{C}$. Infectious titers of all virus stocks were determined by performing the plaque assay on MRC-5 cells. Virus propagation was carried out by low multiplicity of infection (MOI).

Cell culture.HT29 and SW480 cells were provided by Professor Hsei-Wei Wang of National Yang-Ming University, Taiwan. HT29 cells were cultured in Dulbecco's modified Eagle's medium (DMEM) (Gibco, Life Technologies) and SW480 cells were cultured in Leibovitz's L-15 medium (Gibco, Life Technologies) supplemented with $10 \%$ FBS and $1 \%$ penicillin/ streptomycin (Gibco, Life Technologies). MRC-5 cells (ATCC) were cultured in MEM supplemented with $10 \%$ FBS. All cells were cultured at $37^{\circ} \mathrm{C}$ with $5 \% \mathrm{CO}_{2}$.

Sphere formation assays. For stem-like culture, HT29 and SW480 parental cells were resuspended in serum-free DMEM/F12 medium supplemented with $1 \mathrm{X} \mathrm{N}-2$ supplement (Gibco, Life Technologies), $10 \mathrm{ng} / \mathrm{ml}$ recombinant human epidermal growth factor(EGF) (Sigma-Aldrich,USA), $10 \mathrm{ng} / \mathrm{ml}$ basic fibroblast growth factor (bFGF) (Sigma-Aldrich), and $1 \%$ penicillin/streptomycin. Cells were plated at a density of $10^{2}, 10^{3}$ or $10^{4}$ cells/well, as per the experimental requirement, and monitored for 2-3 weeks until spheroids were formed.

Flow cytometry analysis. Flow cytometry assay was used to analyze the expression profile of the cancer stem cell marker CD44. Briefly, $\sim 10^{6}$ cells were washed with phosphate-buffered saline (PBS; Amresco, USA) and labeled with FITC-conjugated anti-CD44 (Miltenyi Biotec, Auburn, CA, USA) in the dark for $30 \mathrm{~min}$ at room temperature. Following incubation, cells were washed twice with PBS and analyzed using a Cytomics FC 500 Series flow cytometry system (Beckman Coulter, Indianapolis, IN, USA).

Immunofluorescence assays and determination of the infectivity rate of $H C M V$ in $C R C$ derived cells. To determine the HCMV infection in cells, immunofluorescence assays were carried out by labeling the non-infected and infected cells with cytomegalovirus immediate early (IE) antibody (GeneTex, USA) and anti-cytomegalovirus pp65 antibody (Abcam, USA). To determine viral infectivity, $10^{3}$ parental and stem-like HT29 cells were infected with HCMV AD169 at MOI of 5 on coverslips. After 24, 48 and $72 \mathrm{~h}$ of infection, infected and non-infected cells were fixed with ice-cold methanol for $10 \mathrm{~min}$ at room temperature and washed thrice with PBS. Cells were blocked with $1 \%$ bovine serum albumin (Sigma-Aldrich) for $1 \mathrm{~h}$ at room temperature, followed by three washes of PBS. Both infected and non-infected cells were stained with 1:20 cytomegalovirus IE antibody for $1 \mathrm{~h}$ in a humidified chamber at $37^{\circ} \mathrm{C}$. Following incubation, cells were washed thrice with 
Table I. The primers used for RT-PCR and real-time PCR.

\begin{tabular}{lll}
\hline Gene & \multicolumn{1}{c}{ Forward (5'-3') } & \multicolumn{1}{c}{ Reverse (5'-3') } \\
\hline RT-PCR & & \\
IE1 & & TCCTCGGTCACTTGTTCAAA \\
US28 & CGACGTTCCTGCAGACTATG & GAAACAGGCAGTGAGTAACG \\
$\beta 2.7 \mathrm{~kb}$ & GTGAACCGCTCATATAGACC & CGGTCAGCAGCCAAACAATC \\
GAPDH & AAGATGTTGCGATGCGGTTG & TCCACCACCCTGTTGCTGTA \\
qPCR & ACCACAGTCCATGCCATCAC & \\
IE1 & & GAGCAGACTCTCAGAGGATCG \\
US28 & AAGCGGCCTCTGATAACCAAG & GTATAATTTGTGAGACGCGACA \\
$\beta 2.7 \mathrm{~kb}$ & GTACCACAGCATGAGCTTTC & CGGTCAGCAGCCAAACAATC \\
Wnt 11 & AAGATGTTGCGATGCGGTTG & GTCCTTGAGCAGAGTCCT \\
FZD7 & GACACAAGACAGGCAGTG & TGTATCTCCCACTCGCCTTC \\
CTNNB & AAGACTTGCAGGACGATGCT & CATCCCTTCCTGTTAGTTG \\
GSK3 3 & GTGCTATCTGTCTGCTCT & CGCAATCGGACTATGTTAC \\
GAPDH & AAGTTAGCAGAGACAAGGA & TCCACGATACCAAAGTTGTCATG \\
& CTGCCCCCTCTGCTGATG &
\end{tabular}

PBS and probed with an anti-mouse IgG FITC (GeneTex) secondary antibody (1:2,000 dilution) for $1 \mathrm{~h}$ in a humidified chamber at $37^{\circ} \mathrm{C}$. Cells were washed as described above and stained with 4',6-diamidino-2-phenylindole (DAPI). The washing step was repeated and a coverslip was placed on the slide with a mounting agent. The slide was visualized using a fluorescence microscope fitted with a camera for cell counting. Five low-magnification fields were counted for each condition and the percentage of positive cells was calculated by dividing the number of IE-positive cells with the total number of nuclei, followed by multiplication with 100 .

Cell viability and cell proliferation. Cell proliferation was evaluated in triplicates by a colorimetric WST-1 assay. The assay determines cellular viability by measuring the metabolic conversion of a water-soluble tetrazolium salt into a dark red formazan by mitochondrial dehydrogenases. The amount of formazan produced is proportional to the number of live cells, which is expressed as cellular viability. Briefly, $10^{2}$ non-infected and infected cells were seeded in 96-well plates and incubated for $6,12,24,48$ and $72 \mathrm{~h}$. The assay was performed by adding WST-1 (Roche, Germany) directly to culture wells, followed by incubation for $1 \mathrm{~h}$ at $37^{\circ} \mathrm{C}$. Plates were read using DS2 ${ }^{\circledR}$ (Dynex, USA) by measuring the absorbance of the dye at $450 \mathrm{~nm}$ wavelength, with $620 \mathrm{~nm}$ set as a reference wavelength. Each experimental condition was performed in triplicates.

To determine the growth effect of HCMV on infected cells, the cell proliferation was evaluated by direct cell counting. HCMV infected and non-infected cells were seeded at a density of $10^{4}$ cells $/ \mathrm{cm}^{2}$ in 24 -well plates and cultured for 3, 6, 12, 24, 48 and $72 \mathrm{~h}$. Following incubation, cells were washed with PBS and harvested by trypsinization. The cell number was determined following staining with $0.4 \%$ trypan blue by Countess Automated Cell Counter (Invitrogen/Life Technologies). The experiment was repeated thrice and each reaction condition was performed in triplicates.

Migration assays. For Transwell migration assays, dissociated stem-like or adherent parental HT29 and SW480 cells infected or non-infected with AD169 were plated at $10^{3}$ cells $/ \mathrm{cm}^{2}$ on the top chambers containing non-coated membrane with $8 \mu \mathrm{m}$ pore size (Corning, NY, USA). Cells in the top chamber were grown in $100 \mu \mathrm{l}$ serum-free medium, while the lower chamber was filled with $600 \mu \mathrm{l}$ of $10 \%$ FBS-supplemented DMEM/F12. After 6, 12, 24, 48 and $72 \mathrm{~h}$ of infection, cells on the upper side were removed and those under the surface were fixed and stained with crystal violet. The cell number was counted using a microscope at five magnification fields. All assays were performed in triplicates.

Reverse transcription (RT)-PCR and real-time PCR (quantitative $P C R$ ). RNA was extracted using TRIzol (Sigma-Aldrich) and $2 \mu \mathrm{g}$ of RNA from each sample was used for the synthesis of the complementary DNA (cDNA). Reverse transcription was carried out in a reaction containing $2 \mu \mathrm{l}$ of 10X RT buffer, $2 \mu \mathrm{l}$ of 10X RT random primers, $0.8 \mu \mathrm{l}$ of $100 \mathrm{mM} \mathrm{dNTP} \mathrm{mix,} 1 \mu \mathrm{l}$ of MultiScribe ${ }^{\mathrm{TM}}$ reverse transcriptase, $1 \mu \mathrm{l}$ of RNase inhibitor (ABI, USA), and diethyl pyrocarbonate (DEPC)-treated water (total volume of $10 \mu \mathrm{l}$ ). Following reaction, $2 \mu \mathrm{g}$ of total RNA in a total volume of $10 \mu \mathrm{l}$ was added to the master mix. The reverse transcription condition was as follows: $25^{\circ} \mathrm{C}$ for $10 \mathrm{~min}$ and $37^{\circ} \mathrm{C}$ for $120 \mathrm{~min}$, heat inactivation at $85^{\circ} \mathrm{C}$ for $5 \mathrm{~min}$, and cooling on ice. The cDNA synthesized was stored at $-20^{\circ} \mathrm{C}$ until its use for PCR. Real-time PCR reaction was performed by mixing $12.5 \mu 12 \mathrm{X}$ SYBR master mix (ABI), $2 \mu \mathrm{l} \mathrm{cDNA}, 0.25 \mu \mathrm{l}$ primer pair mix $(0.1 \mu \mathrm{M} / \mu 1$ each primer), and $23 \mu \mathrm{l}$ water with the PCR reaction. The PCR cycle was as follows: 1 cycle at $50^{\circ} \mathrm{C}$ for $2 \mathrm{~min}, 1$ cycle at $95^{\circ} \mathrm{C}$ for $10 \mathrm{~min}$, 40 cycles of $95^{\circ} \mathrm{C}$ for $15 \mathrm{sec}, 60^{\circ} \mathrm{C}$ for $30 \mathrm{sec}, 72^{\circ} \mathrm{C}$ for $30 \mathrm{sec}$, and a final extension at $72^{\circ} \mathrm{C}$ for $10 \mathrm{~min}$. Real-time PCR was performed in CFX Connect ${ }^{\mathrm{TM}}$ Real-Time Detection System (Bio-Rad, USA) and the results were analyzed with the CFX Manager $^{\mathrm{TM}}$ Software (Bio-Rad). Gene expression level was normalized with that of glyceraldehyde 3-phosphate dehydrogenase (GAPDH) and the fold change was calculated as $2^{-\Delta \Delta \mathrm{Ct}}$, which is the normalized gene expression $2^{-\Delta \mathrm{Ct}}$ in the infected sample divided by the normalized gene expression $2^{-\Delta \mathrm{Ct}}$ in the non-infected sample. 
A

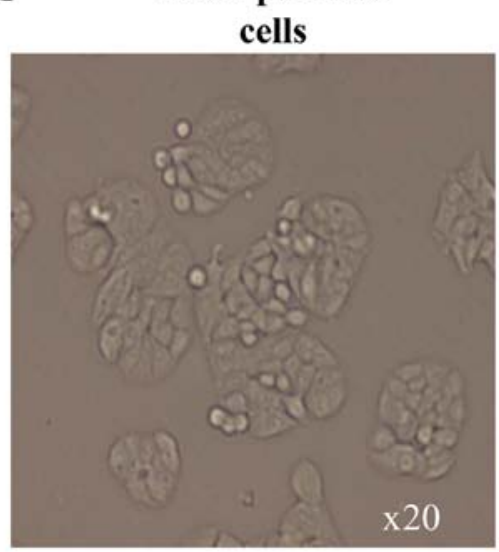

B

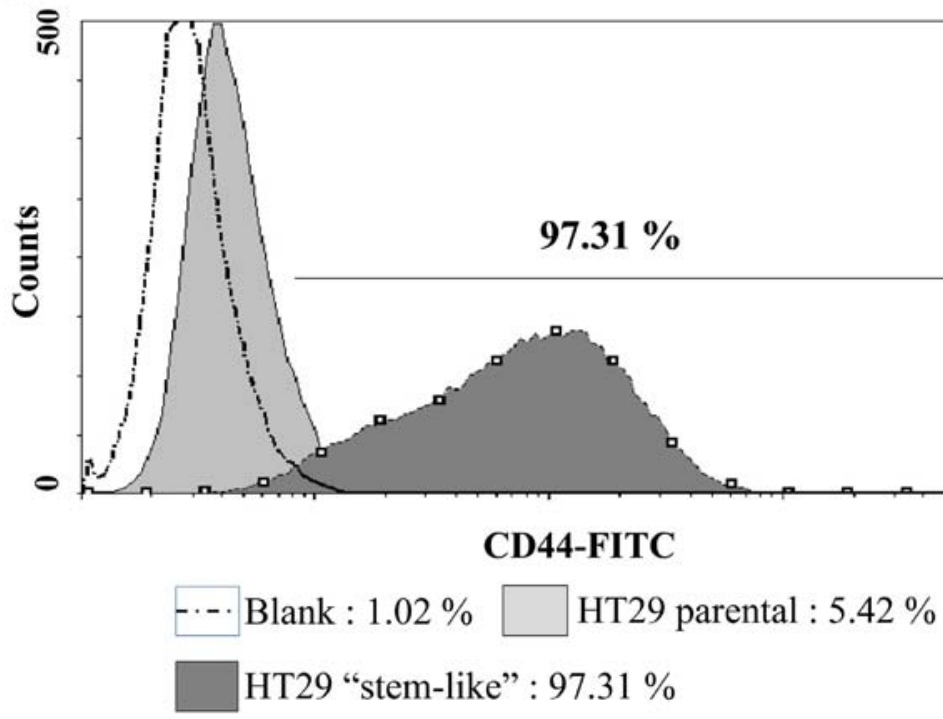

HT29 "stem-like" cells

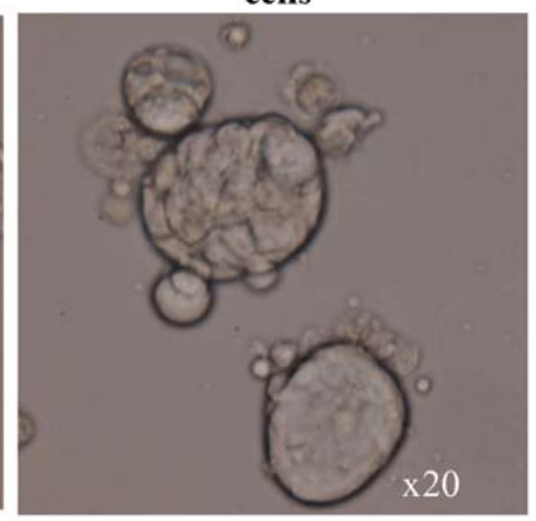

Figure 1. Generation of sphere from HT29 parental. (A) HT29 parental and stem-like cells. (B) Determination of the stemness marker CD44-FITC.

For RT-PCR, the PCR mixture was prepared in a total volume of $25 \mu \mathrm{l}$ and included 2X Taq PLUS PCR Smart mix 1 (SolGent ${ }^{\mathrm{TM}}$, Korea) and the forward and reverse primers at a concentration of $0.3 \mu \mathrm{M}$ each. The volume was adjusted with DEPC-treated water. PCR was performed with an initial denaturation at $94^{\circ} \mathrm{C}$ for $2 \mathrm{~min}$, followed by 35 cycles of $94^{\circ} \mathrm{C}$ for $30 \mathrm{sec}, 55^{\circ} \mathrm{C}$ for $30 \mathrm{sec}, 72^{\circ} \mathrm{C}$ for $30 \mathrm{sec}$, and a final elongation step for $4 \mathrm{~min}$ at $72^{\circ} \mathrm{C}$. The primers used in this study are summarized in Table I.

Analysis of epithelial to mesenchymal transition (EMT) pathways. HCMV AD169 was used to infect $10^{6}$ HT29 stem-like cells at MOI of 5. Cells were harvested and total RNA extracted with TRIzol. The extracted total RNA was sent to Genomics, Taiwan, for human epithelial to mesenchymal transition (EMT) $\mathrm{RT}^{\mathrm{TM}}$ Profiler ${ }^{\mathrm{TM}}$ PCR Array (SABiosciences/Qiagen, Germany) analysis. Briefly, the total RNA was reverse-transcribed and the resulting cDNA analyzed with a 96-well plate quantitative PCR array. The array includes 84 key genes of EMT signal pathways. Gene expression levels were quantified and analyzed with the vendor's web-based software module. Data were collected and normalized based on the mean $\mathrm{Ct}$ value from five housekeeping genes in the arrays (ACTB,
B2M, GAPDH, HPRT1 and RPLP0) and further normalized to the untreated control sample. For fold-change comparisons in cells, non-infected cells were used as the control sample. The fold-change of gene expression was calculated as $2^{-\Delta \Delta C t}$, which is the normalized gene expression $2^{-\mathrm{ACt}}$ in the infected sample divided by the normalized gene expression $2^{-\Delta \mathrm{Ct}}$ in the non-infected sample.

Statistical analyses. Data shown represent results of two independent experiments, with each reaction performed in triplicates. Statistical analyses were carried out by the two-way analysis of variance (ANOVA) and Tukey's multiple comparisons test using GraphPad Prism software to compare between groups. We used the Student's t-test to evaluate two independent experimental groups. A value of $p<0.05$ was considered as statistically significant.

\section{Results}

Increased HCMV infectivity in CRC derived stem-like cells. We assessed HCMV infection in CRC using parental and stem-like HT29 cells as models (Fig. 1A). The enriched HT29 stem-like cells were analyzed using the CD44 marker. 
A

MRC-5

HT29

"stem-like"

HT29

parental

B
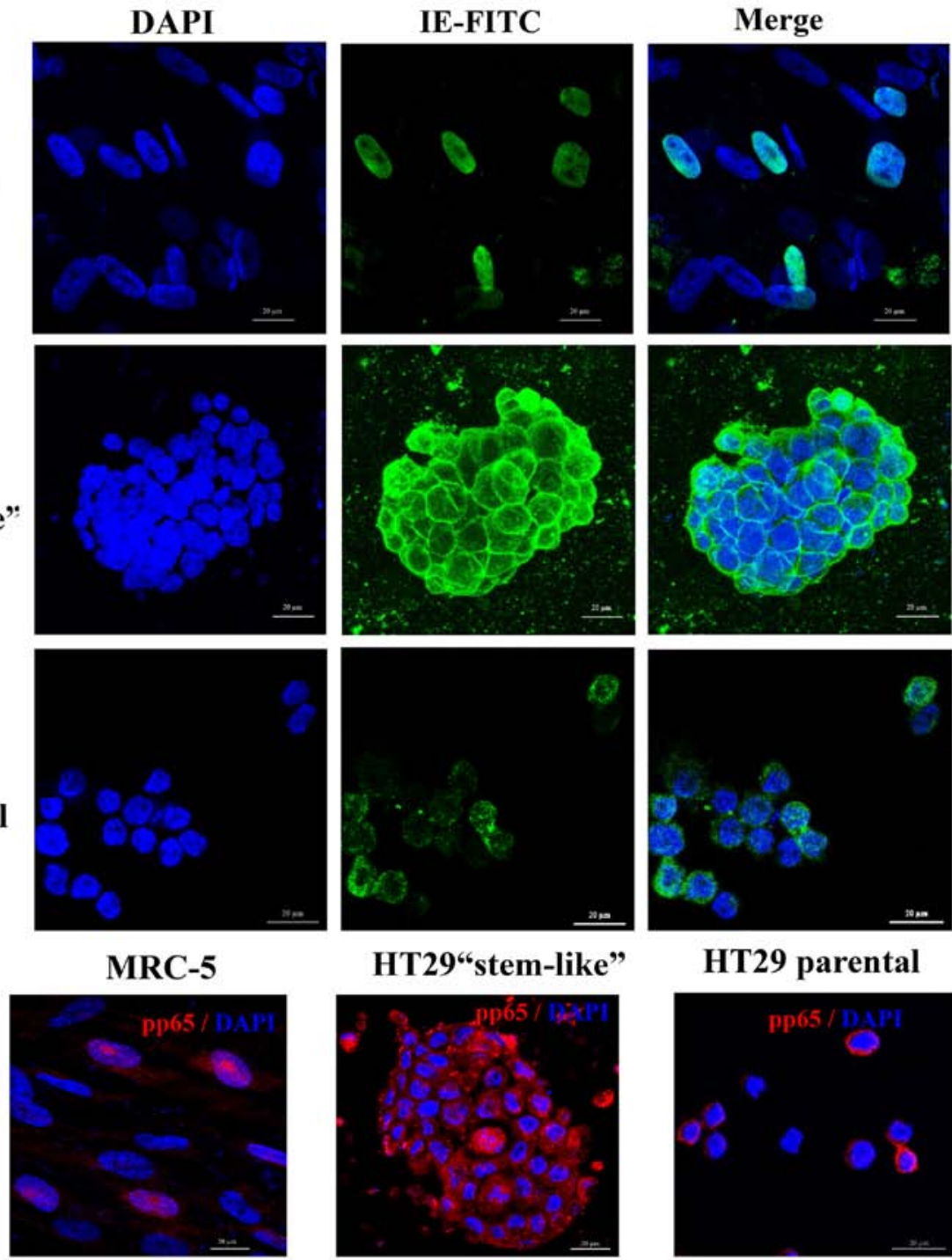

C

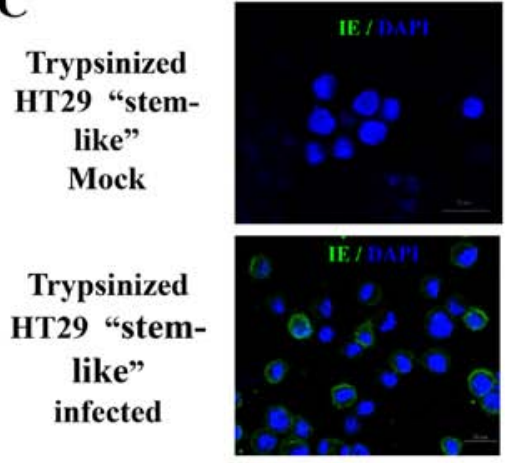

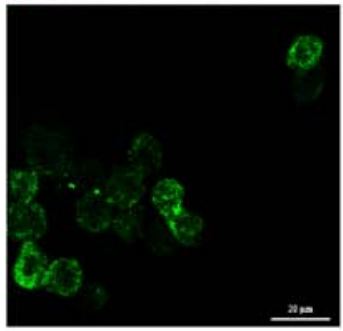

HT29"stem-like"
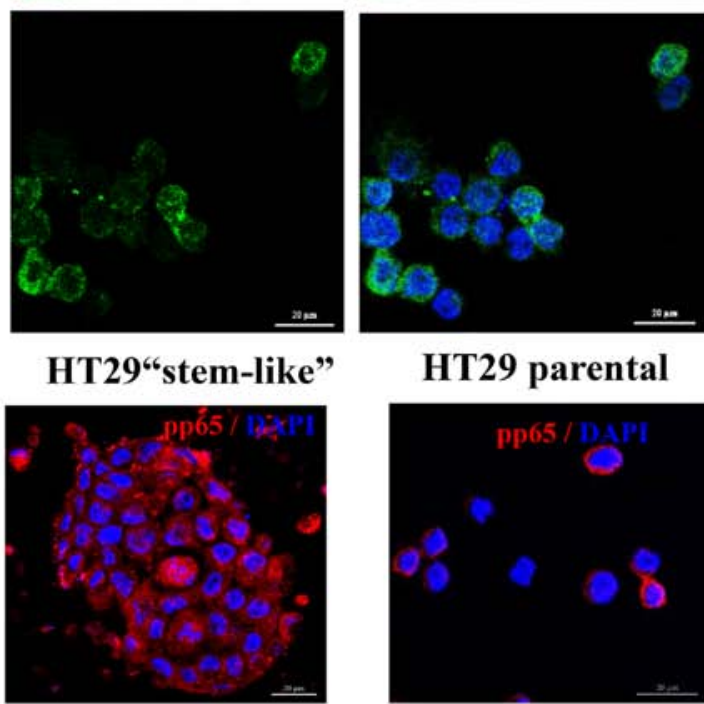

HT29 parental
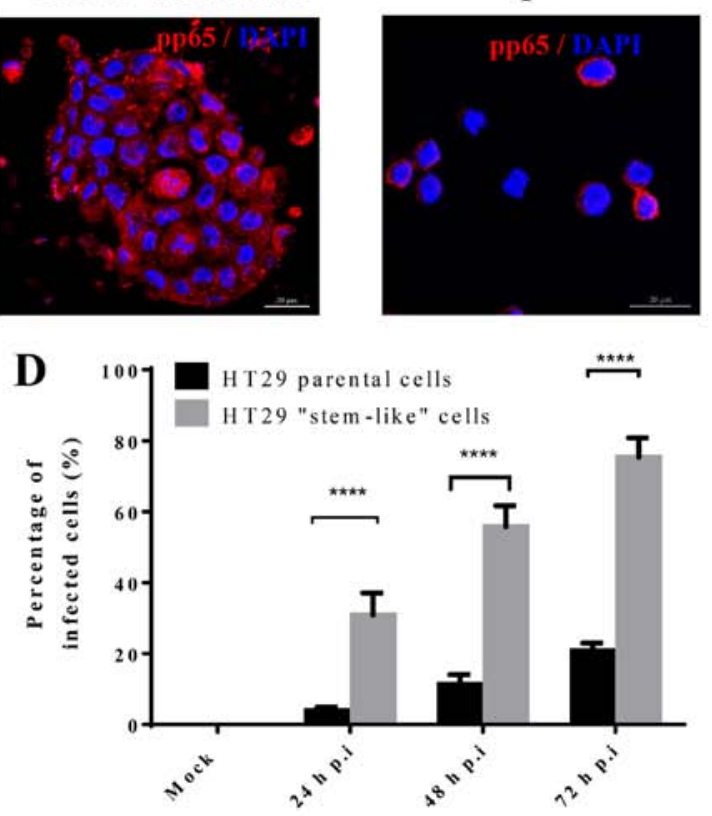

Time of infection

Figure 2. The infection of HCMV laboratory strain AD169 in colorectal cancer-derived cells. (A) HCMV AD169 was used to infect $10^{3}$ parental and stem-like HT29 and MRC-5 (control) cells at MOI of 5 on coverslips, followed by IE and (B) pp65 immunofluorescence. (C) IE-positive cells were observed after counter staining using a fluorescence microscope fitted with a camera. Five low magnification fields were counted for each condition. (D) The percentage of positive cells was calculated by dividing the number of IE-positive cells with the total number of nuclei, followed by multiplication with $100 .{ }^{* * * *} \mathrm{p}<0.0001$ by two-way ANOVA and Tukey's multiple comparisons test.

Flow cytometry data showed that $\mathrm{CD} 44^{+}$cell population was significantly higher $(97.31 \%)$ in the HT29 stem-like cells as compared with the parental HT29 cells (5.42\%) (Fig. 1B). Both cell types were infected with the laboratory strain AD169 and the infection was confirmed by immunofluorescence staining with CMV IE and pp65 (Fig. 2A and B). Infection efficiency was defined as the number of IE-positive cells divided by the total number of nucleated cells. We observed a significantly large number of HT29 stem-like cells infected with AD169 as compared with the HT29 parental cells. To facilitate the 
A

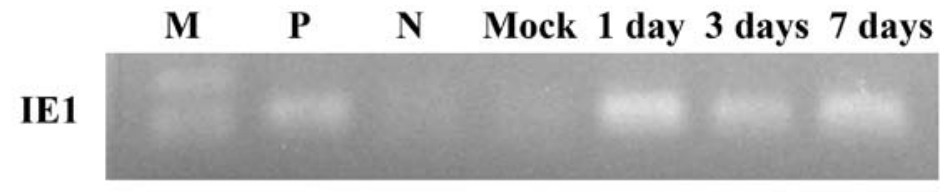

US28

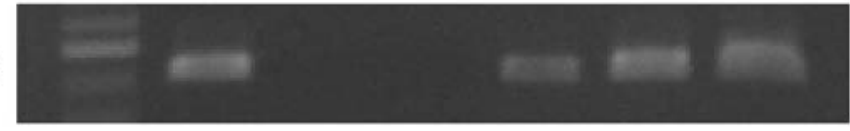

$\beta 2.7 \mathrm{~kb}$

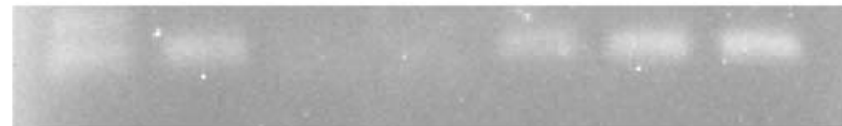

\section{GAPDH}
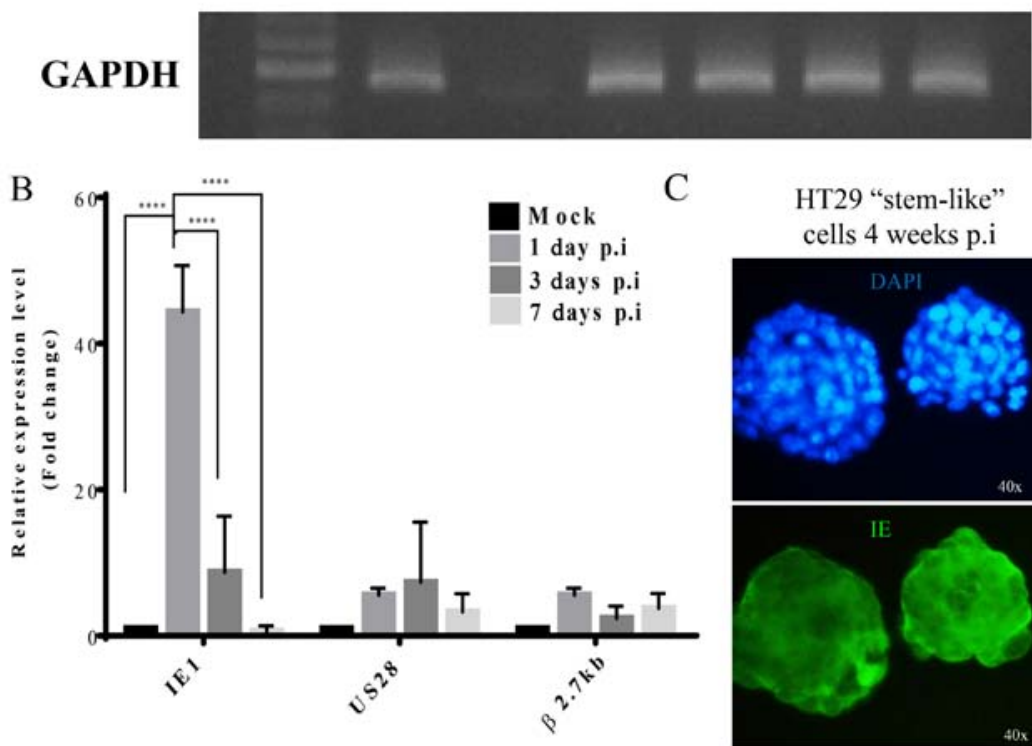

C HT29 "stem-like" cells 4 weeks p.i

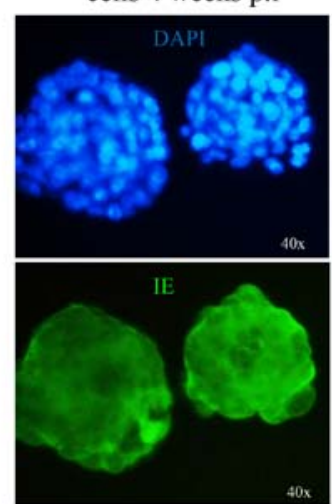

Figure 3. HCMV gene expression. (A) RT-PCR detection of IE1, US28, and $\beta 2.7 \mathrm{~kb}$ transcripts in HACMV AD169-infected HT29 stem-like cells. M, 100 bp DNA ladder; P, positive control; and N, negative control. (B) Semi-quantitative SYBR Green-based RT-qPCR of IE1, US28, and $\beta 2.7 \mathrm{~kb}$ at different time-points following HCMV AD169 infection of HT29 stem-like cells. ${ }^{* * * * *} \mathrm{p}<0.0001$ by two-way ANOVA and Tukey's multiple comparisons test. (C) Determination of HCMV AD169 long-term infection in HT29 stem-like cells (4 weeks).

HT29 stem-like cells count, the infected spheroid cells were dispersed by trypsinization (Fig. 2C). After 24-h infection, IE-positive cells were $\sim 3 \%$ in HT29 parental cells as compared to $29 \%$ in HT29 stem-like cells. After 72 -h infection, $\sim 70 \%$ of HT29 stem-like cells were IE-positive as compared to only 20\% IE-positive HT29 bulk cells (Fig. 2D).

HCMV gene expression. To evaluate the mechanism of HCMV infection in HT29 stem-like cells, we infected these cells with AD169 at MOI of 5 and determined the expression pattern of HCMV genes at different time post-infection using RT-PCR and qPCR. RT-PCR data showed different HCMV gene expression (Fig. 3A). Following AD169 infection, the HCMV IE1 transcript was detected at $24 \mathrm{~h}$, but it decreased at $72 \mathrm{~h}$ and day 7. A small increase in the expression of US28 late gene and $\beta 2.7 \mathrm{~kb}$ was reported at $24 \mathrm{~h}, 72 \mathrm{~h}$, and day 7 after infection.

We used SYBR Green real-time PCR for accurate quantification of the mRNA expression of HCMV genes. Following infection, IE1 expression surged at day 1 but decreased at day 3 and 7 (Fig. 3B), while the IE1 mRNA level decreased at all time-points. On the other hand, no significant differences in US28 and $\beta 2.7 \mathrm{~kb}$ mRNA expression levels were observed after day 1, 3 or 7 of HCMV infection. In HT29 stem-like cells with 4 weeks prolonged AD169 infection, we found that the IE proteins were still expressed (Fig. 3C).

Cell proliferation and viability. We used the colorimetric WST-1 assay to evaluate the viability of HT29 and SW480 cells after AD169 infection. HT29 and SW480 parental and stem-like cells infected with AD169 at different time-points along with the non-infected control were prepared in triplicates. We observed increased cell viability in HT29 and SW480 stem-like cells infected with AD169 (Fig. 4A and B). In comparison to the non-infected cells, HT29 stem-like cells infected with AD169 showed a significant increase in cell proliferation after $12(0.96 \pm 0.05, \mathrm{p}=0.011), 48(3.10 \pm 0.04$, $\mathrm{p}<0.001)$, and $72 \mathrm{~h}(3.31 \pm 0.03, \mathrm{p}<0.0001)$ of infection. Besides, we also observed a significant increase in SW480 stem-like cells infected with AD169 after $24(1.49 \pm 0.02, \mathrm{p}<0.0001)$, $48(2.79 \pm 0.06, \mathrm{p}<0.0001)$, and $72 \mathrm{~h}(3.10 \pm 0.04, \mathrm{p}<0.0001)$ compared to the non-infected cells. No significant growth difference was observed between the HT29 and SW480 parental cells infected with AD169 and non-infected cells. 

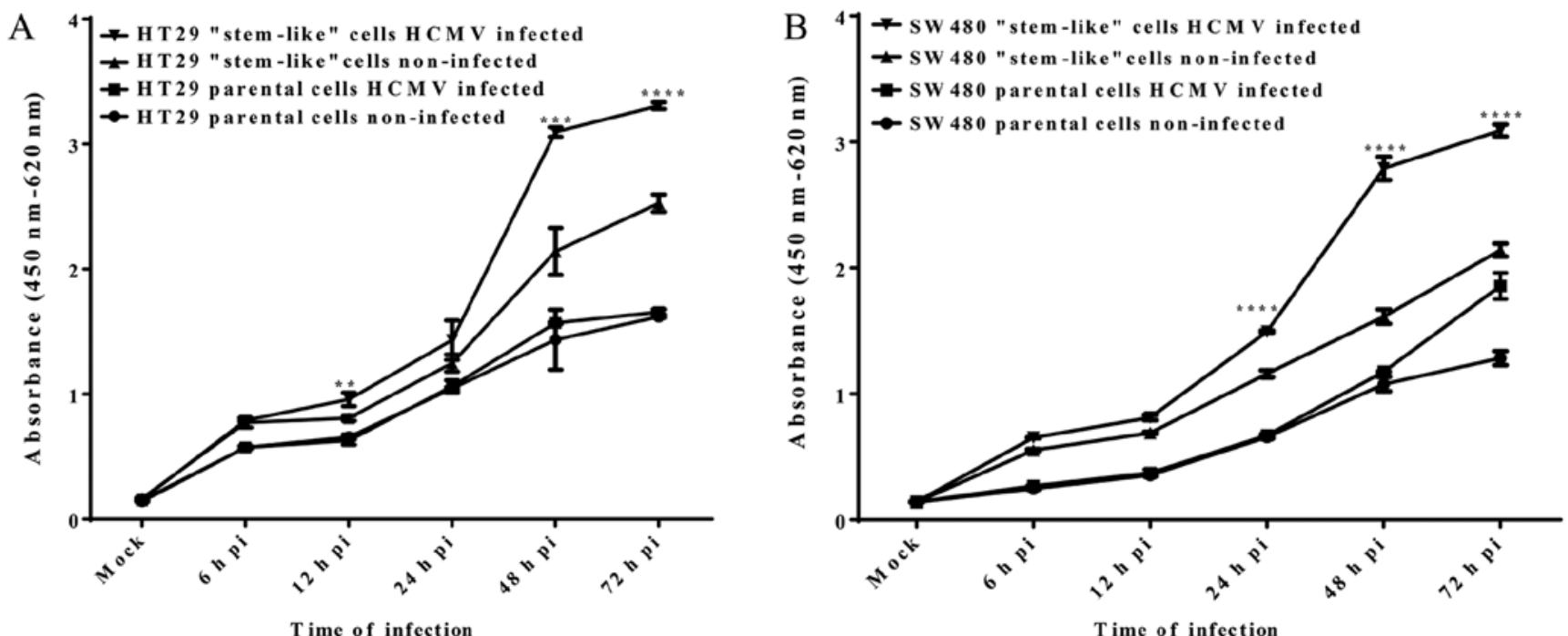

Time of infection
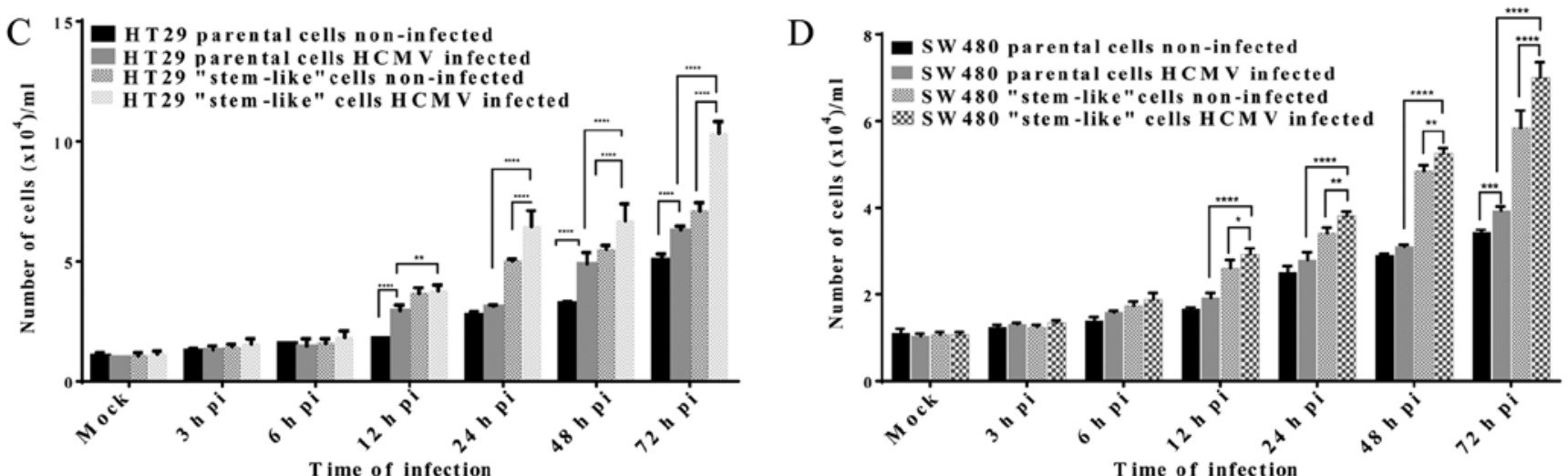

Figure 4. Cell viability and proliferation of AD169-infected and non-infected colorectal cancer-derived cells. HCMV AD169 was used to infect $10^{2}$ parental and stem-like (A) HT29 cells and (B) SW480 cells at MOI of 5. Cells were harvested at 6, 12 24, 48 and $72 \mathrm{~h}$ following infection. Cells were subjected to WST-1 assays. AD169-infected cells showed significant proliferation compared to the non-infected cells. ${ }^{* *} \mathrm{p}<0.01,{ }^{* *} \mathrm{p}<0.001$ and ${ }^{* * *} \mathrm{p}<0.0001$ by Student's t-test. For direct cell proliferation evaluation, $10^{4}$ parental and stem-like (C) HT29 cells and (D) SW480 cells were infected with AD169 at MOI of 5. Cells were harvested at 3,6, 1224,48 and $72 \mathrm{~h}$ following infection and stained with $0.4 \%$ trypan blue. Cells were counted using the Countess Automated Cell Counter. ${ }^{*}$ p $<0.05$, ${ }^{* *} \mathrm{p}<0.01$, and ${ }^{* * * * *} \mathrm{p}<0.0001$ by two-way ANOVA and Tukey's multiple comparisons test.

We evaluated the proliferation of AD169-infected cells by direct cell counting. HT29 and SW480 parental and stem-like cells infected with AD169 at different time-points were harvested, stained with trypan blue, and counted using the Countess Automated Cell Counter. The results revealed that AD169 infection promoted cell growth. Both HT29 and SW480 parental and stem-like cells showed a significant increase in growth following infection $(\mathrm{p}<0.001)$ (Fig. $4 \mathrm{C}$ and D). However, the growth rate was higher for the infected HT29 or SW480 stem-like cells as compared to the infected parental cells at all time-points. In comparison to the infected parental cells, infected stem-like cells showed a 1.3, 2.1, 1.4, and 1.6-fold increase in the growth rate after 12, 24, 48 and $72 \mathrm{~h}$ of infection, respectively. The infected HT29 stem-like proliferated at a significantly faster rate compared either with the non-infected HT29 stem-like or HT29 infected and non-infected parental cells. We observed that SW480 infected stem-like cells also proliferated faster than the parental infected cells. The growth rates after 12, 24, 48 and $72 \mathrm{~h}$ of infection were 1.5, 1.4, 1.7 and 1.8-fold higher than those of the parental infected cells. These data suggest that HCMV infection may promote cell proliferation.
HCMV infection increased cell migration ability. We used Transwell migration assays to study the migration ability of HT29 and SW480 cells with or without AD169 infection. In comparison to the non-infected cells, the infected HT29 and SW480 parental and stem-like cells showed significantly higher migration ability $(\mathrm{p}<0.001)$. However, the number of migrated cells was more in the stem-like cells as compared with the infected parental cells (Fig. 5). In addition, the number of migrated SW480 infected stem-like cells was higher than that of HT29 infected stem-like cells. Thus, HCMV infection increased the migration ability of colorectal-derived cells.

EMT RT $T^{2}$ PCR analyses. To investigate the involvement of EMT in the increased migration ability of these cells, we evaluated the expression of EMT-associated genes in infected and non-infected HT29 stem-like cells using the RT ${ }^{2}$ Profiler $^{\mathrm{TM}}$ PCR array. The heat map (Fig. 6A) showed that most of the EMT-related genes were upregulated after HCMV infection. After 24-h infection, 62 genes were upregulated and 27 genes, downregulated. On the other hand, 35 and 57 EMT-related genes were upregulated and 49 and 27 genes were downregulated after $72 \mathrm{~h}$ and 7 days of infection, respectively. 

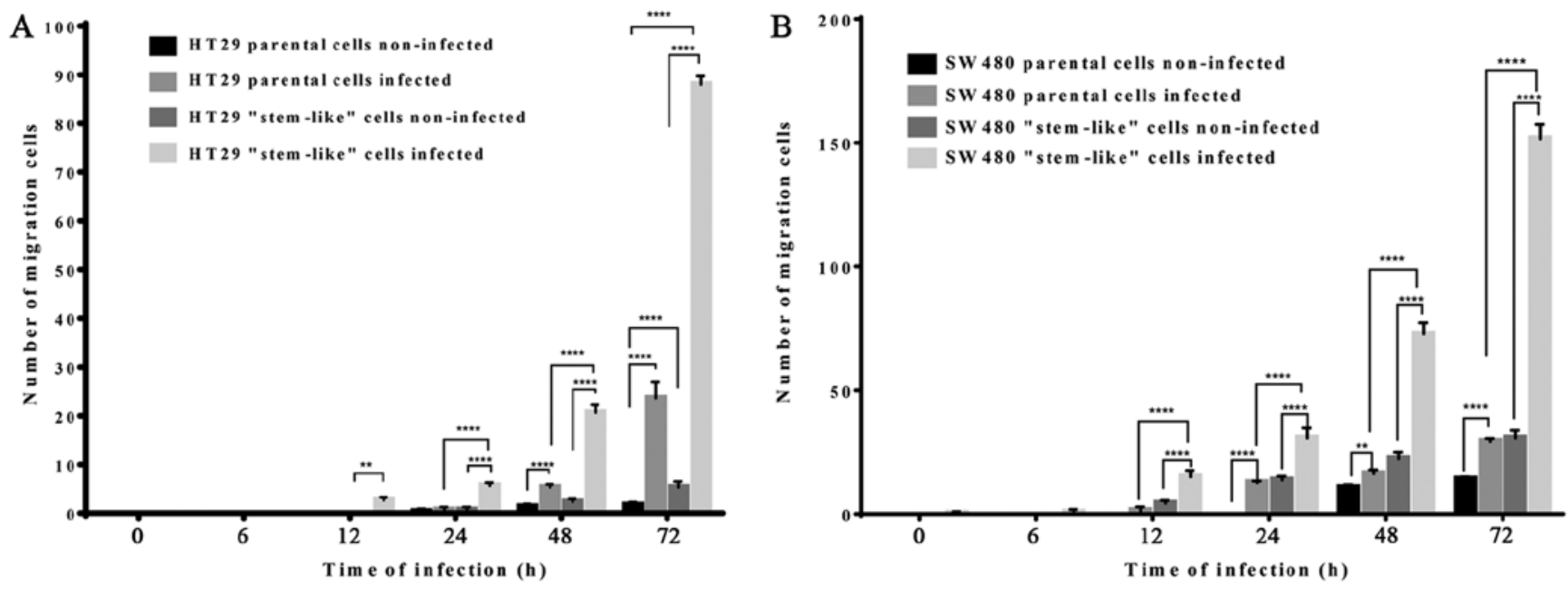

Figure 5. Migration assay of AD169-infected and non-infected cells. Parental and stem-like (A) HT29 cells and (B) SW480 cells were treated with or without HCMV AD169 at MOI of 5. After $72 \mathrm{~h}$ of infection, $10^{4}$ cells were translocated in a 24-Transwell chamber with non-coated membrane and incubated for 6, 12 24,48 and $72 \mathrm{~h}$. The cells under the membrane were stained with crystal violet and counted under the microscope. ${ }^{* * * *} \mathrm{p}<0.001$ and ${ }^{* * * * *} \mathrm{p}<0.0001$ by two-way ANOVA and Tukey's multiple comparisons test.

The array data indicated an increase in the expression of mesenchymal markers such as $\mathrm{N}$-cadherin and fibronectin at all time-points. On the other hand, E-cadherin was downregulated across the infection time. In addition, the expression of EMT drivers such as SNAIL1, SNAIL2/SLUG, ZEB1, and TWIST1 was upregulated following infection (Fig. 6B). We observed an increase in the level of WNT11, frizzled-7 (FZD7), glycogen synthase kinase $3 \beta$ (GSK3 $\beta$ ), and $\beta$-catenin (CTNNB1) during HCMV infection (Fig. 6C). In the subsequent analysis, we designed a panel of primers against WNT signaling (Table I) and evaluated the expression of WNT11, FZD7, GSK3 $\beta$, and $\beta$-catenin by real-time PCR. As shown in Fig. 6D, we observed that the results were compatible with the results of the array.

In comparison to the non-infected cells, those infected showed a significant increase (6-fold) in the expression of WNT11 at day 7 following infection $(\mathrm{p}<0.001)$. The expression of FZD7 in the infected cells was $2.2 \pm 0.94$-fold higher than that in the control cells. No significant different in GSK3 $\beta$ expression was noted. Although there was an increase in the expression of $\beta$-catenin during infection, the difference was not statistically significant.

\section{Discussion}

In this study, we demonstrated that the HCMV strain AD169 infected HT29 stem-like cells with higher efficiency than the HT29 parental cells. The infection rate increased in a time-dependent manner. This result was consistent with a previous study, wherein the efficiency of HCMV infection was higher in 387 and 3832 GSCs as compared with the standard glioma cell line U87 and T98G (26). Fornara et al found that glioblastoma cells infected with HCMV exhibited the ability to grasp those GSC from differentiated condition, thereby enhancing the stem cell phenotype. Consequently, there was an increase in the number of GSCs (28). CSCs have been implicated in the colon carcinogenesis, however their existence had not been experimentally demonstrated until recently. Due to the complexity of their biology and technical problems, the definite identification and isolation is still under debate $(29,30)$. The cell adhesion molecule CD44 was one of the proposed CSC markers. CD44-positive cells seem to exhibit CSC properties, such as a single cell could form a sphere and a xenograft tumor that resembled the original lesion (31). Therefore, in this study we used CD44 as the CSC marker to verify the enriched tumor sphere HT29 cells. Du et al (31) showed that the CD44 was expressed at the bottom of the crypt in colon tissues where the stem cells are distributed as reported (32). Previously, we showed that HCMV viral nucleic acids were mostly found localized at the basal layer of crypt (8) and in this study, we demonstrated that the infection rate was higher in the HT29 stem-like cells. This suggests that HCMV may favor cancer stem cell-like cells for infection.

In the present study, we observed that the patterns of HCMV IE and pp65 localization in HT29 stem-like cells were different from the permissive cell MRC-5. In MRC-5 infected cells, IE and pp65 were expressed in the nucleus while in HT29 stem-like cells they were detected in both nucleus and cytoplasm, but mostly in the cytoplasm. In previous study, the $\beta 2.7 \mathrm{~kb}$ RNA was detected in both intranuclear and cytoplasmic human fibroblasts, but in non-permissive cells, the early transcript is only present within the nucleus (33). In this case, the HT29 stem-like cells might behave as fibroblasts, permissive cells. As showed in this study, HT29 stem-like cells infected with HCMV upregulated TWIST and SNAIL expression and enhanced EMT by downregulating $\mathrm{E}$-cadherin and upregulating the $\mathrm{N}$-cadherin, fibronectin and vimentin $(34,35)$. As anticipated, the resulting cells may acquire fibroblast-like properties. Further study should be carried out to clarify this topographic pattern. We observed a different trend in gene expression at all time-points (Fig. 3A and B). The expression of IE1 gene decreased over time, while expression of US28 and $\beta 2.7 \mathrm{~kb}$ transcripts showed fluctuations, which may be attributed to the different stages in the virus life cycle. HCMV has an organized genome expression. Its replication starts with the immediate early 

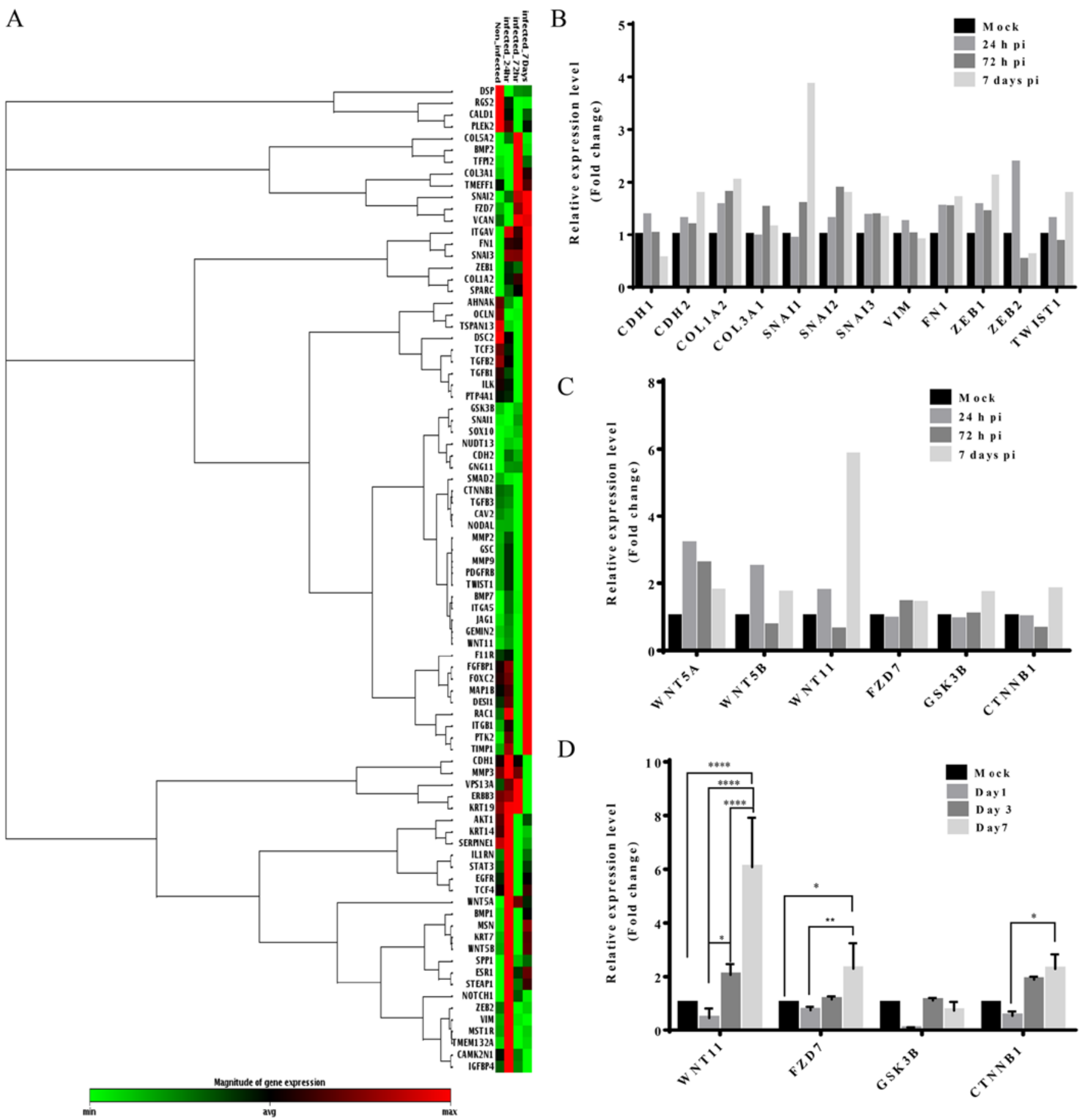

$\mathrm{C}$

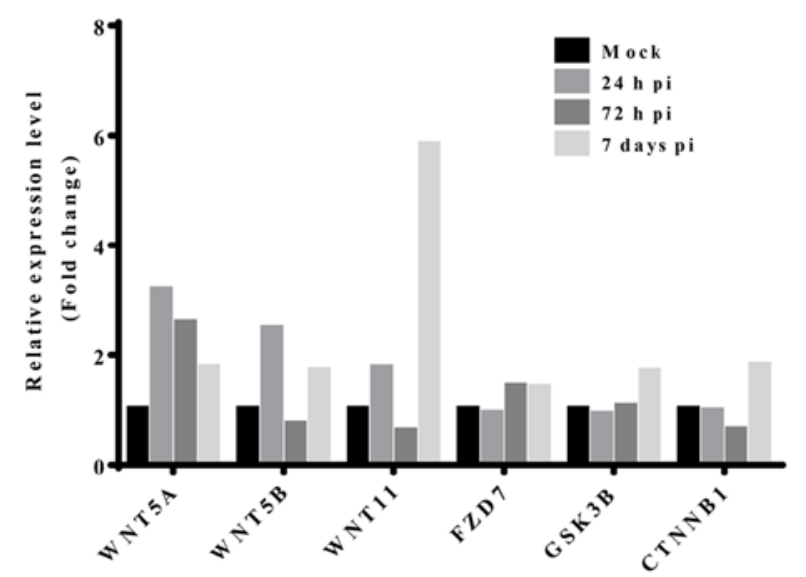

D

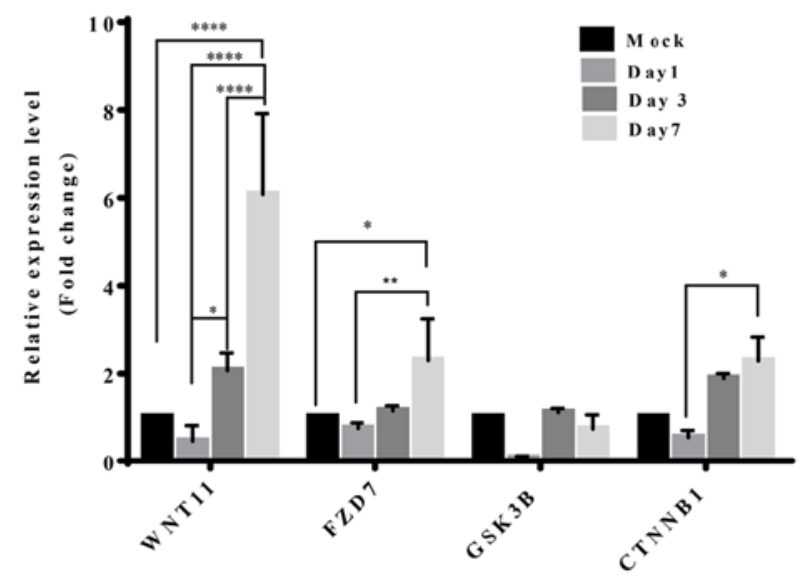

Figure 6. Human EMT RT ${ }^{2}$ Profiler PCR Array of AD169-infected and non-infected cells. (A) HT29 stem-like cells were treated with or without HCMV AD169 at MOI of 5. After different time-points, cells were harvested and the total RNA was extracted and converted to cDNA. The hierarchical clustering of gene signatures was determined using RT ${ }^{2}$ Profiler PCR Array of EMT and illustrated as heat maps (cut off value $>2$ ). (B) The expression of EMT markers and drivers gene of HT29 stem-like cells infected with AD169. (C) Expression of genes related to the WNT signaling pathway in HT29 stem-like cells infected with AD169. (D) Confirmation of WNT11/FZD7 expression in HT29 stem-like cells infected with AD169 and non-infected cells. "p<0.05, ${ }^{* *}$ p $<0.01$, and ${ }^{* * * * * *} \mathrm{p}<0.0001$ by two-way ANOVA and Tukey's multiple comparisons test.

gene expression, followed by the expression of early and late genes. IE1, expressed in the initial phase, regulated the expression of other viral genes such as US28 and $\beta 2.7 \mathrm{~kb}$. The fluctuation in gene expression reported at certain time-points may be a signaling change in the virus replication (36-38).

In this study, we used two CRC-derived cell lines, HT29 and SW480 cells to verify the proliferation after AD169 infection. We found that either HT29 or SW480 infected stem-like cells proliferated more than the non-infected cells or the infected parental and non-infected parental cells. In line with our finding, Fiallos et al, showed that a long-term infection of HCMV in GSC also promoted cell proliferation (26). At the same time, Fornara et al, claimed that the HCMV IE expression induced GBM cells to display stem-like phenotypes and promoted the growth of glioma cancer stem cells (GCSCs) (28). Significant proliferation was shown in the stem-like cells. This 
is consistent with previous clinical finding in our group where the presence of HCMV in CRC patients with stage II, III and IV had a poor outcome (9,39). The tumoral presence of HCMV was associated with a decreased disease-free survival and this might due to the recurrence of CRC. The dysregulation of cell growth signaling in cancerous cells sustains chronic proliferation. Phosphatidylinositol-3-kinase/protein kinase (PI3K/AKT) and mitogen-activated protein kinase (MAPK) activation as well as phosphatase and tensin homologue (PTEN) mutation is known to promote tumorigenesis, as these signaling events stimulate growth, proliferation, and survival of cancer cells (40-43). It had been reported that HCMV gB induced activation of platelet-derived growth factor receptor $\alpha(\mathrm{PDGFR} \alpha)$ and PI3K/AKT, which increased growth and promoted survival and motility in cancer cells (44). HCMV IE proteins have been shown to induce expression of nuclear factor $\kappa \mathrm{B}(\mathrm{NF}-\kappa \mathrm{B})$ subsequently activating the cell survival pathways in tumor cells (45). HCMV IE1 and IE2 were shown to interact with p53 suppressor to prevent the infected cells from undergoing cell growth arrest and apoptosis (46). In addition, HCMV encoded the protein pUL38, which mimics the mammalian target of rapamycin complex-1 by blocking the function of tuberous sclerosis protein 2 (TSC2). Inhibition of TSC 2 by pUL 38 dysregulates the mTOR pathway and induces survival signal in infected cells (47). Furthermore, Reeves et al, showed that $\beta 2.7 \mathrm{~kb}$ interacts with the mitochondrial respiratory chain complex I in neuronal U373 cells and prevents cell death (23).

Accumulated evidence indicates that the HCMV protein US28 is one of the potential proteins that play an important role in tumor progression. US28 was found to induce an invasive and angiogenic phenotype in GBM. US28 has the ability to promote cell growth and induce progression of cell cycle and expression of vascular endothelial growth factor, a proangiogenic factor in NIH3T3. In intestinal cells, US28 was shown to activate $\beta$-catenin by inhibiting GSK3 $\beta$. At the same time, it dysregulated the WNT signaling target genes such as cyclin D, survivin and $c-m y c$, which are important for controlling cell proliferation (48-53). Furthermore, US28 promotes cell migration through the chemokines RANTES and monocyte chemoattractant protein 1 (MCP-1) (48). Another study showed that the interaction of integrin $\alpha v \beta 3$ and PDGFR $\alpha$ with glioma cells resulted in an increase in the cell migratory ability (54). This explains the phenomenon observed in our study, wherein the infected colorectal cells showed greater migration ability.

Studies have proposed that the EMT pathway drives the progression of cancer to an aggressive metastatic stage. During the metastatic stage, tumor cells lose their adhesiveness with the adjacent cells, become more invasive, and develop cancer stemness properties. Several signaling pathways such as WNT/ $\beta$-catenin, Notch, TGF- $\beta$, hedgehog, and EGFR are involved in the EMT process (55-60). In our study, we found that the expression of mesenchymal markers in EMT such as $\mathrm{N}$-cadherin and fibronectin were increased upon infection with HCMV. On the other hand, E-cadherin was suppressed during HCMV infection. E-cadherin functions as a mediator during cell-cell adhesion and the loss of E-cadherin is known to induce EMT. $\beta$-catenin is thought to be secluded in E-cadherin adherent junction. APC malfunction in CRC may result in
GSK3 $\beta$ inhibition by the WNT signaling pathway, leading to the accumulation of $\beta$-catenin in the cell cytoplasm. This will induce the expression of target genes such as $c$-myc and $c y c l i n D$ by the TCF/LEF-1 family transcription factors. Activation of these genes usually stimulates tumor progression (61-64).

The array data show that the expression of WNT11 was high during the infection time course. Therefore, we repeated the experiment by evaluating the expression of related genes such as WNT11, FZD7, GSK3 $\beta$, and $\beta$-catenin. It was confirmed that the expression of these genes was higher in the infected cells as compared with the non-infected cells. Previous studies $(65,66)$ revealed that either the canonical or non-canonical WNT signaling was implicated during the dynamic and reversible EMT and mesenchymal-epithelial transition during CRC progression. The high expression of WNT11 and its ligand FZD7 is reported to enhance proliferation and migration/invasion activities in the colon cancer cells $(67,68)$. These findings explain the phenotypic changes observed in our study, wherein HCMV infection enhanced the proliferation and migratory ability of cells. This study successfully established a CRC culture model with high HCMV infectivity to facilitate investigation of the underlying mechanisms. Further studies are needed to identify the HCMV genes involved in these phenotypic changes.

\section{Acknowledgements}

This study was supported by the grants from the Ministry of Science and Technology (MOST 105-2314-B-075-055-MY2-1 to Y-J.C. and MOST 104-2320-B-010-017 to J.C.H.). We also thank Dr Hui-Yu Chuang for her experimental assistance.

\section{References}

1. World Health Organization fact sheet Cancer. February, 2017. http://www.who.int/mediacentre/factsheets/fs297/en/.

2. Tanaka T: Colorectal carcinogenesis: Review of human and experimental animal studies. J Carcinog 8: 5, 2009.

3. Moore HG, Baxter NN and Guillem JG: Colorectal cancer: Epidemiology, etiology, and molecular basis. In: The ASCRS Textbook of Colon and Rectal Surgery. 2nd edition. Beck D (ed). Springer Science, Business Media, pp669-690, 2011.

4. Colussi D, Brandi G, Bazzoli F and Ricciardiello L: Molecular pathways involved in colorectal cancer: Implications for disease behavior and prevention. Int J Mol Sci 14: 16365-16385, 2013.

5. Markowitz SD and Bertagnolli MM: Molecular origins of cancer: Molecular basis of colorectal cancer. N Engl J Med 361: 2449-2460, 2009.

6. Jemal A, Bray F, Center MM, Ferlay J, Ward E and Forman D: Global cancer statistics. CA Cancer J Clin 61: 69-90, 2011.

7. Harkins L, Volk AL, Samanta M, Mikolaenko I, Britt WJ, Bland KI and Cobbs CS: Specific localisation of human cytomegalovirus nucleic acids and proteins in human colorectal cancer. Lancet 360: 1557-1563, 2002.

8. Chen HP, Jiang JK, Chen CY, Chou TY, Chen YC, Chang YT, Lin SF, Chan $\mathrm{CH}$, Yang CY, Lin $\mathrm{CH}$, et al: Human cytomegalovirus preferentially infects the neoplastic epithelium of colorectal cancer: A quantitative and histological analysis. J Clin Virol 54: 240-244, 2012.

9. Chen HP, Jiang JK, Lai PY, Chen CY, Chou TY, Chen YC, Chan CH, Lin SF, Yang CY, Chen CY, et al: Tumoral presence of human cytomegalovirus is associated with shorter disease-free survival in elderly patients with colorectal cancer and higher levels of intratumoral interleukin-17. Clin Microbiol Infect 20: 664-671, 2014.

10. Dimberg J, Hong TT, Skarstedt M, Löfgren S, Zar N and Matussek A: Detection of cytomegalovirus DNA in colorectal tissue from Swedish and Vietnamese patients with colorectal cancer. Anticancer Res 33: 4947-4950, 2013. 
11. Bai B, Wang X, Chen E and Zhu H: Human cytomegalovirus infection and colorectal cancer risk: A meta-analysis. Oncotarget 7: 76735-76742, 2016

12. Crough $T$ and Khanna R: Immunobiology of human cytomegalovirus: From bench to bedside. Clin Microbiol Rev 22: 76-98, 2009.

13. Murphy E, Yu D, Grimwood J, Schmutz J, Dickson M, Jarvis MA Hahn G, Nelson JA, Myers RM and Shenk TE: Coding potential of laboratory and clinical strains of human cytomegalovirus. Proc Natl Acad Sci USA 100: 14976-14981, 2003.

14. Harkins LE, Matlaf LA, Soroceanu L, Klemm K, Britt WJ, Wang W, Bland KI and Cobbs CS: Detection of human cytomegalovirus in normal and neoplastic breast epithelium. Herpesviridae 1: 8, 2010.

15. Samanta M, Harkins L, Klemm K, Britt WJ and Cobbs CS: High prevalence of human cytomegalovirus in prostatic intraepithelial neoplasia and prostatic carcinoma. J Urol 170: 998-1002, 2003.

16. Melnick M, Sedghizadeh PP, Allen CM and Jaskoll T: Human cytomegalovirus and mucoepidermoid carcinoma of salivary glands: Cell-specific localization of active viral and oncogenic signaling proteins is confirmatory of a causal relationship. Exp Mol Pathol 92: 118-125, 2012.

17. Cobbs CS, Harkins L, Samanta M, Gillespie GY, Bharara S, King PH, Nabors LB, Cobbs CG and Britt WJ: Human cytomegalovirus infection and expression in human malignant glioma. Cancer Res 62: 3347-3350, 2002.

18. Rahbar A, Orrego A, Peredo I, Dzabic M, Wolmer-Solberg N, Strååt K, Stragliotto G and Söderberg-Nauclér C: Human cytomegalovirus infection levels in glioblastoma multiforme are of prognostic value for survival. J Clin Virol 57: 36-42, 2013.

19. Stragliotto G, Rahbar A, Solberg NW, Lilja A, Taher C, Orrego A, Bjurman B, Tammik C, Skarman P, Peredo I, et al: Effects of valganciclovir as an add-on therapy in patients with cytomegalovirus-positive glioblastoma: A randomized, doubleblind, hypothesis-generating study. Int J Cancer 133: 1204-1213, 2013.

20. Wolmer-Solberg N, Baryawno N, Rahbar A, Fuchs D, Odeberg J, Taher C, Wilhelmi V, Milosevic J, Mohammad AA, Martinsson T, et al: Frequent detection of human cytomegalovirus in neuroblastoma: A novel therapeutic target? Int J Cancer 133: 2351-2361, 2013.

21. Michaelis M, Doerr HW and Cinatl J Jr: The story of human cytomegalovirus and cancer: Increasing evidence and open questions. Neoplasia 11: 1-9, 2009.

22. Söderberg-Nauclér C and Nelson JY: Human cytomegalovirus latency and reactivation - a delicate balance between the virus and its host's immune system. Intervirology 42: 314-321, 1999.

23. Reeves MB, Davies AA, McSharry BP, Wilkinson GW and Sinclair JH: Complex I binding by a virally encoded RNA regulates mitochondria-induced cell death. Science 316 1345-1348, 2007.

24. Cobbs CS, Soroceanu L, Denham S, Zhang W, Britt WJ, Pieper R and Kraus $\mathrm{MH}$ : Human cytomegalovirus induces cellular tyrosine kinase signaling and promotes glioma cell invasiveness J Neurooncol 85: 271-280, 2007.

25. Cobbs CS, Soroceanu L, Denham S, Zhang W and Kraus MH: Modulation of oncogenic phenotype in human glioma cells by cytomegalovirus IE1-mediated mitogenicity. Cancer Res 68: 724-730, 2008

26. Fiallos E, Judkins J, Matlaf L, Prichard M, Dittmer D, Cobbs C and Soroceanu L: Human cytomegalovirus gene expression in long-term infected glioma stem cells. PLoS One 9: e116178, 2014.

27. Soroceanu L, Matlaf L, Khan S, Akhavan A, Singer E, Bezrookove V, Decker S, Ghanny S, Hadaczek P, Bengtsson H, et al: Cytomegalovirus immediate-early proteins promote stemness properties in glioblastoma. Cancer Res 75: 3065-3076, 2015.

28. Fornara O, Bartek J Jr, Rahbar A, Odeberg J, Khan Z, Peredo I, Hamerlik P, Bartek J, Stragliotto G, Landázuri N, et al: Cytomegalovirus infection induces a stem cell phenotype in human primary glioblastoma cells: Prognostic significance and biological impact. Cell Death Differ 23: 261-269, 2016.

29. Abdul Khalek FJ, Gallicano GI and Mishra L: Colon cancer stem cells. Gastrointest Cancer Res (Suppl 1): S16-S23, 2010

30. Papailiou J, Bramis KJ, Gazouli M and Theodoropoulos G: Stem cells in colon cancer. A new era in cancer theory begins. Int $\mathrm{J}$ Colorectal Dis 26: 1-11, 2011.

31. Du L, Wang H, He L, Zhang J, Ni B, Wang X, Jin H, Cahuzac N, Mehrpour M, Lu Y, et al: CD44 is of functional importance for colorectal cancer stem cells. Clin Cancer Res 14: 6751-6760, 2008 .
32. Gorham H, Sugino T, Woodman AC and Tarin D: Cellular distribution of CD44 gene transcripts in colorectal carcinomas and in normal colonic mucosa. J Clin Pathol 49: 482-488, 1996.

33. Wu TC, Lee WA, Pizzorno MC, Au WC, Chan YJ, Hruban RH, Hutchins GM and Hayward GS: Localization of the human cytomegalovirus $2.7-\mathrm{kb}$ major early beta-gene transcripts by RNA in situ hybridization in permissive and nonpermissive infections. Am J Pathol 141: 1247-1254, 1992.

34. Cano A, Pérez-Moreno MA, Rodrigo I, Locascio A, Blanco MJ, del Barrio MG, Portillo F and Nieto MA: The transcription factor snail controls epithelial-mesenchymal transitions by repressing E-cadherin expression. Nat Cell Biol 2: 76-83, 2000.

35. Yang J, Mani SA, Donaher JL, Ramaswamy S, Itzykson RA, Come C, Savagner P, Gitelman I, Richardson A and Weinberg RA: Twist, a master regulator of morphogenesis, plays an essential role in tumor metastasis. Cell 117: 927-939, 2004.

36. Mocarski E and Shenk T: Cytomegaloviruses. In: Fields Virology. 5th edition. Knipe D and Howley P (eds). Lippincott Williams and Wilkins, Philadelphia, PA, pp2701-2772, 2007.

37. Fortunato EA and Spector DH: Regulation of human cytomegalovirus gene expression. Adv Virus Res 54: 61-128, 1999.

38. Landolfo S, Gariglio M, Gribaudo G and Lembo D: The human cytomegalovirus. Pharmacol Ther 98: 269-297, 2003.

39. Chen HP, Jiang JK, Chan CH, Teo WH, Yang CY, Chen YC, Chou TY, Lin CH and Chan YJ: Genetic polymorphisms of the human cytomegalovirus UL144 gene in colorectal cancer and its association with clinical outcome. J Gen Virol 96: 3613-3623, 2015.

40. Jiang BH and Liu LZ: PI3K/PTEN signaling in angiogenesis and tumorigenesis. Adv Cancer Res 102: 19-65, 2009.

41. Suman S, Kurisetty V, Das TP, Vadodkar A, Ramos G, Lakshmanaswamy R and Damodaran C: Activation of AKT signaling promotes epithelial-mesenchymal transition and tumor growth in colorectal cancer cells. Mol Carcinog 53 (Suppl 1): E151-E160, 2014

42. Porta C, Paglino C and Mosca A: Targeting PI3K/Akt/mTOR signaling in cancer. Front Oncol 4: 64, 2014.

43. Mayer IA and Arteaga CL: The PI3K/AKT pathway as a target for cancer treatment. Annu Rev Med 67: 11-28, 2016.

44. Cobbs C, Khan S, Matlaf L, McAllister S, Zider A, Yount G, Rahlin K, Harkins L, Bezrookove V, Singer E, et al: HCMV glycoprotein B is expressed in primary glioblastomas and enhances growth and invasiveness via PDGFR-alpha activation. Oncotarget 5: 1091-1100, 2014.

45. Yurochko AD, Kowalik TF, Huong SM and Huang ES: Human cytomegalovirus upregulates NF-kappa B activity by transactivating the NF-kappa B p105/p50 and p65 promoters. J Virol 69: 5391-5400, 1995

46. Castillo JP, Yurochko AD and Kowalik TF: Role of human cytomegalovirus immediate-early proteins in cell growth control J Virol 74: 8028-8037, 2000.

47. Moorman NJ, Cristea IM, Terhune SS, Rout MP, Chait BT and Shenk T: Human cytomegalovirus protein UL38 inhibits host cell stress responses by antagonizing the tuberous sclerosis protein complex. Cell Host Microbe 3: 253-262, 2008.

48. Streblow DN, Soderberg-Naucler C, Vieira J, Smith P, Wakabayashi E, Ruchti F, Mattison K, Altschuler Y and Nelson JA: The human cytomegalovirus chemokine receptor US28 mediates vascular smooth muscle cell migration. Cell 99: 511-520, 1999.

49. Maussang D, Verzijl D, van Walsum M, Leurs R, Holl J, Pleskoff O, Michel D, van Dongen GA and Smit MJ: Human cytomegalovirus-encoded chemokine receptor US28 promotes tumorigenesis. Proc Natl Acad Sci USA 103: 13068-13073, 2006.

50. Maussang D, Langemeijer E, Fitzsimons CP, Stigter-van Walsum M, Dijkman R, Borg MK, Slinger E, Schreiber A, Michel D, Tensen CP, et al: The human cytomegalovirus-encoded chemokine receptor US28 promotes angiogenesis and tumor formation via cyclooxygenase-2. Cancer Res 69: 2861-2869, 2009.

51. Slinger E, Maussang D, Schreiber A, Siderius M, Rahbar A, Fraile-Ramos A, Lira SA, Söderberg-Nauclér C and Smit MJ: HCMV-encoded chemokine receptor US28 mediates proliferative signaling through the IL-6-STAT3 axis. Sci Signal 3: ra58, 2010.

52. Bongers G, Maussang D,MunizLR,Noriega VM,Fraile-Ramos A, Barker N, Marchesi F, Thirunarayanan N, Vischer HF, Qin L, et al: The cytomegalovirus-encoded chemokine receptor US28 promotes intestinal neoplasia in transgenic mice. J Clin Invest 120: $3969-3978,2010$ 
53. Cai ZZ, Xu JG, Zhou YH, Zheng JH, Lin KZ, Zheng SZ, Ye MS He Y, Liu CB and Xue ZX: Human cytomegalovirus-encoded US28 may act as a tumor promoter in colorectal cancer. World J Gastroenterol 22: 2789-2798, 2016.

54. Ding Q, Stewart J Jr, Olman MA, Klobe MR and Gladson CL: The pattern of enhancement of Src kinase activity on platelet-derived growth factor stimulation of glioblastoma cells is affected by the integrin engaged. J Biol Chem 278: 39882-39891, 2003.

55. Zhang J, Tian X-J and Xing J: Signal transduction pathways of EMT induced by TGF- $\beta$, SHH, and WNT and their crosstalks. J Clin Med 5: 41, 2016.

56. Derynck R, Muthusamy BP and Saeteurn KY: Signaling pathway cooperation in TGF- $\beta$-induced epithelial-mesenchymal transition. Curr Opin Cell Biol 31: 56-66, 2014

57. Takebe N, Harris PJ, Warren RQ and Ivy SP: Targeting cancer stem cells by inhibiting Wnt, Notch, and Hedgehog pathways. Nat Rev Clin Oncol 8: 97-106, 2011.

58. Takebe N, Miele L, Harris PJ, Jeong W, Bando H, Kahn M, Yang SX and Ivy SP: Targeting Notch, Hedgehog, and Wnt pathways in cancer stem cells: Clinical update. Nat Rev Clin Oncol 12: 445-464, 2015

59. Gonzalez DM and Medici D: Signaling mechanisms of the epithelial-mesenchymal transition. Sci Signal 7: re8, 2014.

60. Jin D, Fang Y, Li Z, Chen Z and Xiang J: Epithelial-mesenchymal transition-associated microRNAs in colorectal cancer and drugtargeted therapies (Review). Oncol Rep 33: 515-525, 2015.

61. Bienz $M$ and Clevers H: Linking colorectal cancer to Wnt signaling. Cell 103: 311-320, 2000
62. Polakis P: Wnt signaling and cancer. Genes Dev 14: 1837-1851, 2000.

63. Novellas de Munt L, Antas P and Li VS: Targeting Wnt signaling in colorectal cancer. A review in the theme: Cell signaling: proteins, pathways and mechanisms. Am J Physiol Cell Physiol 309: C511-C521, 2015.

64. Basu S, Haase G and X Ben-Ze'ev A: Wnt signaling in cancer stem cells and colon cancer metastasis. F1000Res 5: F1000 Faculty Rev-699, 2016.

65. Brabletz T, Jung A, Reu S, Porzner M, Hlubek F, KunzSchughart LA, Knuechel R and Kirchner T: Variable beta-catenin expression in colorectal cancers indicates tumor progression driven by the tumor environment. Proc Natl Acad Sci USA 98: 10356-10361, 2001.

66. Howard S, Deroo T, Fujita Y and Itasaki N: A positive role of cadherin in Wnt/ $\beta$-catenin signalling during epithelial-mesenchymal transition. PLoS One 6: e23899, 2011.

67. Ueno K, Hazama S, Mitomori S, Nishioka M, Suehiro Y, Hirata H, Oka M, Imai K, Dahiya R and Hinoda Y: Downregulation of frizzled-7 expression decreases survival, invasion and metastatic capabilities of colon cancer cells. Br J Cancer 101: 1374-1381, 2009.

68. Nishioka M, Ueno K, Hazama S, Okada T, Sakai K, Suehiro Y, Okayama N, Hirata H, Oka M, Imai K, et al: Possible involvement of Wnt11 in colorectal cancer progression. Mol Carcinog 52: 207-217, 2013. 